\title{
A new didolodontid mammal from the late Paleocene-earliest Eocene of Laguna Umayo, Peru
}

Javier N. Gelfo and Bernard Sigé

Acta Palaeontologica Polonica 56 (4), 2011: 665-678 doi: http://dx.doi.org/10.4202/app.2010.0067

A previously undescribed tooth from the Muñani Formation at the Laguna Umayo locality, Peru, represents the new

didolodontid Umayodus raimondi gen. et sp. nov., here diagnosed by the presence of a well developed metastylid and ectostylid, and a twinned hypoconulid. This taxon is closely related to the middle Paleocene genera Escribania and Raulvaccia from the locality of Punta Peligro in Patagonia, Argentina. Phylogenetic analysis here performed indicates that they constitute a monophyletic group within Didolodontidae, supported by five derived characters: the hypocone well developed and close to the protocone; the strongly concave precingulum; the contact between the postcristid and the entoconid; the contact of the crista pre-paraconular, precingulum and parastyle; and the mesiodistal enlargement of the $\mathrm{m} 3$ talonid. Their paleogeographic distribution fit with those of the actual Andean Region of the Austral Kingdom. The previously assumed Thanetian-Ypresian age assignment for the Laguna Umayo LU3 fauna is here reinforced by faunistic comparisons with the earliest Eocene Murgon fauna, in Australia, and the Itaboraian South American Land Mammal Age, represented from faunas of Patagonia, Argentina and São José de Itaboraí, Brazil.

Key words: Mammalia, Didolodontidae, Condylarthra, Paleocene, Eocene, Austral Kingdom, South America, Peru.

Javier N. Gelfo [jgelfo@fcnym.unlp.edu.ar] División Paleontología Vertebrados, Museo de La Plata, Paseo del Bosque s/n B1900FWA La Plata, Argentina; Bernard Sigé [bernard-sige@ orange.fr] Institut des Sciences de l'Evolution (UMR - CNRS 5125), Université Montpellier-2, Place Eugène Bataillon, Montpellier, France.

This is an open-access article distributed under the terms of the Creative Commons Attribution License (for details please see creativecommons.org), which permits unrestricted use, distribution, and reproduction in any medium, provided the original author and source are credited. 
FoF Full text $(244.3 \mathrm{kB})$ 